\title{
Michał Roman
}

Warsaw University of Life Sciences

e-mail:michal_roman@sggw.pl

\section{CURRENT STATE AND PROSPECTS FOR THE DEVELOPMENT OF TOURISM, INCLUDING AGRITOURISM, IN THE REPUBLIC OF MOLDOVA}

\section{STAN OBECNY I PERSPEKTYWY ROZWOJU TURYSTYKI, W TYM AGROTURYSTYKI W REPUBLICE MOLDAWII}

DOI: $10.15611 /$ pn.2017.473.42

JEL Classification: Q12, Q13, Q15, Q17

Summary: The article aims to present the essence of the development of tourism in the Republic of Moldova. It draws attention to the attractiveness of tourism in the context of the development of the region and the social-cultural values of the country's rural areas. The article makes use of the database of the World Tourism Organisation, the National Bureau of Statistics of the Republic of Moldova and information collected during study visits to the staff of the Association of Tourism Development in Moldova (in Kishinev, the capital city of Moldova, in June and July 2016). Moldova is a small country with a lot of tourist attractions. There are over 15,000 anthropogenic attractions for tourists and over 300 nature areas. In 2014, 96,000 tourists visited Moldova (7.5\% more than in the preceding year), generating $\$ 226$ million in revenues. There were seven providers of tourist services in 2005, and there were already 26 in 2015. The author was a co-founder of four agritourism clusters in Moldova developed within an international project.

Keywords: tourism, tourist movement, rural tourism, agritourism, Moldova.

Streszczenie: Celem artykułu jest zaprezentowanie istoty rozwoju turystyki, w tym agroturystyki w Republice Mołdawii. W opracowaniu zwrócono uwagę na atrakcyjność turystyki w aspekcie rozwoju regionu oraz na wartości społeczno-kulturowe obszarów wiejskich tego kraju. Wykorzystano dane Światowej Organizacji Turystyki, Głównego Urzędu Statystycznego Republiki Mołdawii oraz informacje zebrane od pracowników Stowarzyszenia Rozwoju Turystyki w Mołdawii podczas wyjazdów studyjnych (w czerwcu i lipcu 2016 roku do Kiszyniowa). Mołdawia cieszy się wielką różnorodnością atrakcji turystycznych. Istnieje tu ponad 15 tys. antropogenicznych atrakcji turystycznych i ponad 300 obszarów przyrodniczych. W 2014 roku Mołdawię odwiedziło 96 tys. turystów (7,5\% więcej niż w roku poprzednim), generując przychody na poziomie 226 mln dolarów. W 2005 roku działalność 
agroturystyczną prowadziło 7 usługodawców, natomiast w 2015 roku - 26. Autor artykułu w ramach międzynarodowego projektu był współzałożycielem 4 klastrów agroturystycznych na terenie Mołdawii.

Słowa kluczowe: turystyka, ruch turystyczny, turystyka wiejska, agroturystyka, Mołdawia.

\section{Introduction}

Moldova is one of the least popular tourist destinations in whole wide Europe. The country is also the poorest one on the old continent. It is poorly developed and depends on import of fuels and raw materials. Most probably this is why the number of flights to Moldova offered by air carriers is small. The state, which used to be a Soviet republic, declared independence in 1991. Fields and vineyards dominate the landscape. The main waterways have formed deep rocky ravines that are mainly covered in forests. The south, towards the Black Sea, is covered in Buchach steppe. It is worth visiting old wooden Orthodox churches and monasteries in Moldova. Still living rural folklore and winemaking traditions are also real tourist attractions. [http://www.kiszyniow.msz.gov.pl]

Moldovan vineyards give abundant crops of grapes for the production of table wine that has medicinal and dietary properties. The vine varieties cultivated there are very high quality. One of the main wine companies is Cricova situated near Kishinev. It possesses one of the world's biggest wine cellars with $130 \mathrm{~km}$ of underground tunnels, galleries and rooms. Each tunnel looks like a street with barrels of wine instead of houses on both sides. Each tunnel is called after the type of wine that matures there, e.g. Aligote, Feteasca or Cabernet. The Cricova's cellars have the biggest collection of wine. Most wine producers give access to their facilities only to organised groups of tourists. Such visits are very popular although they are not cheap.

The State Enterprise Quality Wines Industrial Complex in Milestii Mici, where one can drive a car on the streets of a part of the underground facility, is also an interesting place for wine lovers. Other high-quality wine cellars allowing visitors entry include Cricova, Cojusna, Straseni, Romanesti and some others.

A tourist can expect warm reception and hospitality in each of the dozens of vineyards along "the tourist wine route". Visitors may choose their favourite type of wine, e.g. Milestii Mici ones, which mature in cellars for years until they taste originally. The wines from Purcari and Ciumai cellars are also famous. The tourist wine route may help a visitor to understand Moldova better: this is the only country on the world map whose shape reminds a bunch of grapes.

In addition, Moldova is a country of old culture and folk traditions that constitute an inherent part of its cultural heritage. Apart from the fact that the ethnic diversity of the region has not destroyed the traditional system, it has even enriched it by adding 
new colours and creating an original conglomerate of customs, habits and rituals, which can be still observed in Moldovan villages. Many traditional holidays are a mixture of elements typical of the rural, agricultural and religious calendar.

\section{Article's aim, material and methods}

The article aims to present the essence of the development of tourism, including agritourism, in the Republic of Moldova. It draws attention to the attractiveness of tourism in the context of the development of the region and the social-cultural values of the country's rural areas. The article makes use of the database of the World Tourism Organisation, the National Bureau of Statistics of the Republic of Moldova and information collected during study visits to the staff of the Association of Tourism Development in Moldova (in Kishinev, the capital city of Moldova, in June and July 2016). Detailed information is presented in tables and discussed with the use of a descriptive method. The author was a co-founder of four agritourism clusters in Moldova developed within an international project.

\section{State of tourism development in the Republic of Moldova}

Moldova is a small country with a variety of tourist attractions, which are close to the main cities and hoteling centres. There are over 15,000 tourist attractions and over 3,000 registered and essential, from the tourists' point of view, nature areas. The tourism sector in this country is coordinated by the Tourism Agency of the Republic of Moldova (a separate state administration organ subordinate directly to the government). It has its own Collegium and is supported by the Advisory Council. [Miron et al. 2015, p. 45]

There are a few thousand tourist resorts, about 400 settlements of the CucuteniTripolie civilisation times, about 50 ancient fortified towns, 500 early medieval settlements, many medieval fortresses, including six fortresses built of stone (in a different state of preservation), over 1,000 protected architectural antiquities and about 50 Orthodox churches. This heritage is relatively equally dispersed all over the country. Unfortunately, the state of their degradation makes them unattractive for the country's own citizens. [Miron et al. 2015, p. 45]

Tourist visits enable visitors to directly get to know various tourist attractions in Moldovan towns. In 2015, 37,700 Moldovans travelled along the domestic tourist routes, i.e. 1,003.4 people daily. Travelling in Moldova is still a cheap product easily available to many clients. The cost is 6-7 euros per person in a group tour of up to $100 \mathrm{~km}$ of a round trip, and 50-60 euros per person in group visits to wineries and wine tasting. Vineyards, the capital city Kishinev and Orthodox churches, which are included in the general offer of the domestic and international tourism, are most popular Moldovan attractions [Data of the Association...] 
There are about 20 active professional tourist guides who know the routes to domestic attractions. They are employed in about 85 tourist agencies and educational institutions in Kishinev. There are also 324 local tourist guides employed in 108 museums, who on demand organise trips to some regional tourist attractions outside the museums. Thus, one can hire a local guide to whatever tourist attraction in Moldova within a 30-km radius [Data of the Association...].

There are 249 institutions offering night accommodation. The number is doubled by entities that offer accommodation occasionally and are not registered businesses. Tourists find accommodation mainly in hotels, guesthouses and holiday villages. Luxurious (4-5-star) hotels account for $22.2 \%$ and the biggest share in the provision of accommodation services belongs to medium quality (3-star) hotels, and is $27 \%$. Accommodation with a lower standard (1-2 stars) accounts for about $12.7 \%$ and these are lodging facilities that have not been modernised yet. In 2015, hotels and similar facilities were in the majority (39\%) followed by resorts for children (24\%), and guesthouses accounted for only about $10 \%$. It must be highlighted that these are approximate figures because there is a lack of data on the real situation in hotels and small guesthouses in rural areas. The increase in the number of agritourism farms is the most spectacular: from seven farms in 2005 to 26 in 2015, especially in rural areas or places rich in wildlife and cultural attractions. This results from a growing interest in visiting Moldova and nurturing traditions in rural areas as well as organic agriculture. One can notice an upward trend in the number of hotels and similar facilities, especially those situated in cities or close to them. Other accommodation facilities report little annual fluctuation, which is caused by high infrequency of financing from public funds (in case of summer camps) or business profitability (reporting statistical and tax data). [Data of the National Bureau...; compare Śmieja 2007, p. 17]

Over the last 10 years, the number of 3-star tourist accommodation facilities in Moldova has been continually growing and tripled. Luxurious night accommodation (4-5 star facilities) has been dynamically developing and has grown 2.8 times. But the development of "economy" class facilities has been more moderate. [Data of the National Bureau...]

In general, tourists are offered double rooms. The rate is relatively at the same level in hotels and similar facilities classified in the last 10 years. It must be mentioned that because of non-classification of youth camps and other summer facilities (where more people share a room), the rate only partially reflects the reality. [Data of the National Bureau...]

The dynamic of change in the number of rooms is similar to that of the number of beds, which means there is continuous investment in traditional forms of accommodation (single/double rooms) and little interest in compact and affordable forms of accommodation (e.g. hostels). With the increase in accommodation capacity, one can observe a different dynamic in the number of nights spent in accommodation facilities. And thus, until 2009, the number of nights considerably decreased, ca. 
by $8 \%$ annually. After 2010 , however, an annual increase to 1.5 million nights was reported in 2015. [Miron et al. 2016, pp. 213-214]

A considerable fall is observed in the use of accommodation capacity, which over the period of 10 years fell from $31 \%$ to $21.4 \%$ in 2015 . It can be explained by uncertain statistical data provision by the tourism sector. [Data of the National Bureau...]

In general, over the last 10 years, the number of nights decreased by $10.6 \%$ mainly because of a fall in the number of tourists going to summer camps and the structure of accommodation facilities. A similar decline took place in the number of nights spent in the biggest guesthouses, holiday villages and summer camps $(-14.14 \%)$. It must be pointed out that an average tourist stay in Moldova was about 5.4 days in 2015 and had been relatively stable over the last 4 years. [Data of the National Bureau...]

The evolution of the number of people staying for the night in various accommodation facilities demonstrates a prevalence of hotels and similar facilities, and a constant fall in summer camps. At the same time, after the period of decreasing, since 2010 the number of stays in summer villages (tourist resorts) has been growing. Tourist guesthouses report relatively constant number, i.e. about 9-10 thousand visitors annually. [Data of the National Bureau...]

After a fall reported until 2009 (1.4 million nights), the number of overnight stays in hotels slightly rose to 1.5 million of nights spent by both domestic and foreign tourists. The hoteling sector has been best at regaining accommodation capacity. Other facilities report occasional growths, but also a continuous decline (summer camps, guesthouses).

At the same time, the use of accommodation facilities varies depending on the type of facility. The rate of an average domestic use of accommodation capacity was falling by about $1 \%$ annually over the last ten years and was about $35 \%$ in 2015 . [Miron et al. 2016, pp. 213-214]

In case of summer camps for children, the rate of accommodation capacity use was relatively high (55.5\%) and exceeded the country's average by about $20 \%$. It is due to a large number of children who need this kind of services in summer and the organised form of the service offered by particular facilities. [Data of the National Bureau....]

In general, the tourism sector reports an increase in the scope of accommodation services offered. In the period 2005-2015, the number of available accommodation places slightly increased, by $5.5 \%$ in total, mainly because of the exclusion of about $26.8 \%$ of places available in summer villages from the turnover and thanks to an increase in the potential of summer camps for children by only $7.4 \%$. However, other accommodation facilities, such as tourist and agritourism guesthouses, reported a considerable rise (accommodation base grew 4.3 times) and hotels (their bed number grew by $27 \%$ ). This redistribution in the accommodation base occurred as a result of tourists' preferences. They seek a higher standard of stay for a shorter 
period. At the same time, the decrease in the sector in 2015 was dictated by the economic situation. [Data of the National Bureau...]

Camps for children have the highest accommodation capacity in the Republic of Moldova (13,600 beds). In 2014, the accommodation capacity of summer villages (tourist resorts) fell below the level reported by hotels. The exclusion of tourist resorts from turnover has serious consequences for the organisation of tourism in rural destinations. [Data of the National Bureau...; Miron et al. 2016, pp. 213-214]

\section{State of regional tourism development in the Republic of Moldova}

Moldova can be divided into a few regions. As far as they are concerned, the Central Region has the biggest number of accommodation places $(8,591)$ and is followed by the North $(4,479)$ and the South $(3,535)$. The Centre has an accommodation base similar to Kishinev, having almost the same capacity as the other regions together. There were no spectacular fluctuations in accommodation capacity in regions (except for 2015), which results from a higher level of conservatism in the hoteling sector. [Miron et al. 2016, pp. 213-214]

In the Northern Region, there was a slight but constant fall in the number of beds from 5,264 in 2008 to 4,479 in 2015. The biggest drop was recorded in 2015 (about 11\%), mainly in the summer accommodation facilities. It must be mentioned, however, that summer accommodation facilities do not demonstrate good statistical reporting discipline. While in Sângerei and Edinet Districts annual accommodation capacity was at the same level, the number of beds in Soroca fell dramatically by 47\%. [Data of the National Bureau...; Miron et al. 2016, pp. 213-214]

In the Central Region, there was a slight drop (after a relative rise) in the number of beds from 9,399 in 2008 to 8,591 in 2015. The biggest decrease was in 2015 in summer accommodation facilities. However, one should notice poor (statistical and other) reporting discipline demonstrated by summer accommodation facilities. In both monitored regions accommodation capacity fell slightly. [Data of the National Bureau...; Miron et al. 2016, pp. 213-214]

In the Southern Region, there was a constant growth (after a relative stagnation) from 2,230 beds in 2008 to 2,405 beds in 2015. The biggest increase was in 2015 (about 47\%). [Miron et al. 2016, pp. 213-214]

\section{Structure of tourist movement and accommodation services in the Republic of Moldova}

An average tourist stay in Moldova is about 5.4 days, mainly because of a big share of longer overnight stays in summer facilities. However, a detailed analysis of data allows for calculating an average length of stay in different types of accommodation facilities. And so, summer camps for children are organised for 9-10 days; sanatoria 
also offer longer stays with spa treatment. However, most commercial tourist stays last 2-3 days. [Data of the National Bureau...]

Employment in tourism decreased in the last 10 years by about $15.8 \%$ from 1,900 to 1,600 employees in 2015. It resulted from the decrease in the number of tourists staying in hotels. [Data of the National Bureau...]

The United Nations World Tourism Organisation (UNWTO) presents an analysis of trends in global tourist movement each year. The report entitled "UNWTO Tourism Highlights" presents statistical data concerning individual states and dependent territories. The most popular tourist destinations include France, Spain and Italy. It is not surprising that the USA and China are among those states. However, the most interesting part of the ranking is its end, which reveals places that are visited least often. There are small and not easily accessible and exotic islands among them, but European countries also won positions at the end of the list, e.g. Moldova. In every country, the number of foreigners crossing the border of a particular state (with the exception of those leaving the country the same day) is taken into account. Thus, the statistics do not take into consideration a big share of local border traffic (shopping, work) nor a part of transit. The exception is Kyrgyzstan, where one-day tourists are calculated, and Moldova, where facilities providing accommodation services (e.g. hotels) produce statistics. Thus, Kyrgyzstan's statistics are overstated and

Table 1. Number of tourists and revenues from tourism in the former Soviet Union countries

\begin{tabular}{|c|c|c|c|c|c|c|c|c|}
\hline \multirow{2}{*}{ State } & \multicolumn{4}{|c|}{ Number of tourists (thousand) } & \multicolumn{4}{|c|}{ Revenues from tourism (million \$) } \\
\hline & 2010 & 2011 & 2012 & 2013 & 2010 & 2011 & 2012 & 2013 \\
\hline Armenia & 687 & 758 & 843 & 957 & 411 & 448 & 454 & 458 \\
\hline Azerbaijan & 1280 & 1562 & 1986 & - & 657 & 1287 & 2433 & 2365 \\
\hline Belarus & 120 & 116 & 119 & 137 & 440 & 487 & 685 & 722 \\
\hline Estonia & 2372 & 2665 & 2744 & 2868 & 1073 & 1249 & 1226 & 1393 \\
\hline Georgia & 1067 & 1319 & 1790 & 2065 & 659 & 955 & 1411 & 1720 \\
\hline Kazakhstan & 3393 & 4093 & 4438 & 4926 & 1005 & 1209 & 1347 & 1460 \\
\hline Kyrgyzstan & 855 & 2278 & 2406 & - & 284 & 640 & 435 & - \\
\hline Latvia & 1373 & 1493 & 1435 & 1536 & 640 & 771 & 745 & 864 \\
\hline Lithuania & 1507 & 1775 & 1900 & - & 958 & 1323 & 1317 & 1467 \\
\hline Moldova & 64 & 75 & 89 & 96 & 173 & 195 & 213 & 226 \\
\hline Poland & 12470 & 13350 & 14840 & 15845 & 9526 & 10683 & 10938 & 10938 \\
\hline Russia & 20262 & 22674 & 25727 & 28356 & 8831 & 11328 & 10759 & 11988 \\
\hline Tajikistan & - & - & - & - & 4 & 3 & 3 & - \\
\hline Turkmenistan & - & - & - & - & & - & - & - \\
\hline Ukraine & 21203 & 21415 & 23013 & 24671 & 3788 & 4294 & 4842 & 5083 \\
\hline Uzbekistan & 975 & - & - & - & 121 & - & - & - \\
\hline
\end{tabular}

Source: [Data of the World...]. 
Moldova's understated. [https://www.fly4free.pl] Table 1 presents the number of tourists and revenues from tourism in the former Soviet Union countries.

The research methodology for Moldova is extremely unfavourable, because it only takes into account tourists registered in hotels and other tourist facilities. However, it is true that Moldova is the country that is least often visited by foreign tourists. Moreover, according to other rankings, in 2014 Moldova was $9^{\text {th }}$ in the classification of countries least often visited with 96 thousand tourists [http://mkt. unwto.org/en] (7.5\% more than in the former year) generating revenues at the level of 226 million dollars. [https://www.fly4free.pl] In another classification in 2014, Moldova was $5^{\text {th }}$ with 11 thousand tourists annually. [http://zalajkowane.pl] Table 2 presents characteristic features of tourist movement in the Republic of Moldova in the period 2004-2013.

Table 2. Characteristic features of tourist movement in the Republic of Moldova in the period 2004-2013

\begin{tabular}{|c|c|c|c|c|c|c|}
\hline Year & $\begin{array}{c}\text { Number } \\
\text { of } \\
\text { tourists }\end{array}$ & $\begin{array}{c}\text { Number } \\
\text { of nights }\end{array}$ & $\begin{array}{c}\text { Average } \\
\text { number } \\
\text { of days of } \\
\text { stay }\end{array}$ & $\begin{array}{c}\text { Number } \\
\text { of foreign } \\
\text { tourists }\end{array}$ & $\begin{array}{c}\text { Number of nights } \\
\text { spent by foreign } \\
\text { tourists }\end{array}$ & $\begin{array}{c}\text { Average number } \\
\text { of days of foreign } \\
\text { tourists' stay }\end{array}$ \\
\hline 2004 & 372 & 1854 & 4.98 & 229 & 1571 & 6.86 \\
\hline 2005 & 1807 & 3799 & 2.10 & 1003 & 2492 & 2.48 \\
\hline 2006 & 7763 & 50047 & 6.45 & 3102 & 24728 & 7.97 \\
\hline 2007 & 8932 & 56778 & 6.36 & 3488 & 29797 & 8.54 \\
\hline 2008 & 11392 & 59429 & 5.22 & 2981 & 23242 & 7.80 \\
\hline 2009 & 12346 & 49486 & 4.01 & 2500 & 12917 & 5.17 \\
\hline 2010 & 13290 & 43583 & 3.28 & 2383 & 7219 & 3.03 \\
\hline 2011 & 11701 & 37317 & 3.19 & 2417 & 8482 & 3.51 \\
\hline 2012 & 11570 & 36895 & 3.19 & 3881 & 15240 & 3.93 \\
\hline 2013 & 11526 & 34513 & 2.99 & 4353 & 15380 & 3.53 \\
\hline
\end{tabular}

Source: [Data of the National Bureau...].

According to the data presented in the table, every year the number of tourists, including foreign tourists, in Moldova rises. Table 3 presents the use of accommodation facilities and other forms of tourism by tourists in the period 2004-2013.

A big number of tourists (about 38.9\%), Moldovan residents and non-residents, find accommodation in summer facilities (holiday camps and villages) as well as in tourist guesthouses and agritourism farms in the rural areas in Moldova. In 2015, they accounted for 109 thousand altogether. The rates are obtained thanks to the relatively reasonable prices and conditions of moderate comfort as well as because of a relatively uniform system of allocation of summer facilities in the country. [Data of the National Bureau...] 
Table 3. Use of accommodation facilities and other forms of tourism by tourists in the period 2004-2013

\begin{tabular}{|c|c|c|c|c|c|c|c|c|}
\hline \multirow{2}{*}{ Year } & \multicolumn{2}{|c|}{ Residents of Moldova and foreign tourists } & \multicolumn{4}{c|}{ Foreign tourists } \\
\cline { 2 - 10 } & Total & $\begin{array}{c}\text { Guest- } \\
\text { houses and } \\
\text { agritourism } \\
\text { facilities }\end{array}$ & $\begin{array}{c}\text { Holiday } \\
\text { resorts } \\
\text { and other } \\
\text { facilities }\end{array}$ & $\begin{array}{c}\text { Camps } \\
\text { for } \\
\text { children }\end{array}$ & $\begin{array}{c}\text { Guest- } \\
\text { Total } \\
\text { houses and } \\
\text { agritourism } \\
\text { facilities }\end{array}$ & $\begin{array}{c}\text { Holiday } \\
\text { resorts } \\
\text { and other } \\
\text { facilities }\end{array}$ & $\begin{array}{c}\text { Camps } \\
\text { for } \\
\text { children }\end{array}$ \\
\hline 1 & 2 & 3 & 4 & 5 & 6 & 7 & 8 & 9 \\
\hline 2004 & 286731 & 372 & 48718 & 42798 & 68829 & 229 & 685 & 248 \\
\hline 2005 & 301656 & 1807 & 47889 & 54040 & 67235 & 1003 & 74 & 641 \\
\hline 2006 & 311966 & 7763 & 49854 & 60460 & 62771 & 3102 & 242 & 341 \\
\hline 2007 & 314619 & 8932 & 52504 & 69450 & 70302 & 3488 & 372 & 234 \\
\hline 2008 & 280550 & 11392 & 27587 & 71712 & 73288 & 2981 & 1080 & 239 \\
\hline 2009 & 227888 & 12346 & 24708 & 60897 & 59563 & 2500 & 1480 & 350 \\
\hline 2010 & 229893 & 13290 & 18386 & 63350 & 63593 & 2383 & 2171 & 195 \\
\hline 2011 & 248309 & 11701 & 25826 & 62945 & 75000 & 2417 & 3231 & 35 \\
\hline 2012 & 268189 & 11570 & 39522 & 53044 & 88956 & 3881 & 3789 & 35 \\
\hline 2013 & 271541 & 11526 & 33027 & 53642 & 95640 & 4353 & 4823 & 46 \\
\hline
\end{tabular}

Source: [Data of the National Bureau...].

After a major decrease in the period 2006-2010 caused by the Dniester River floods, holiday villages (tourist resorts) are gradually recovering. In 2015, the owners managed to accommodate 47 thousand tourists. Domestic guesthouses serve a relatively stable number of tourists (about 9,300 people in 2015), with little annual fluctuation. [Miron et al. 2015, p. 28]

\section{Development and state of agritourism in the Republic of Moldova}

In 2005, there were seven agritourism businesses in Moldova and in 2015, the number rose to 26 service providers, including 20 registered farms. [Data of the National Bureau...] Agritourism business is run in the owner's family's household and agricultural facilities and in their natural, cultural and social surrounding. It is addressed to guests who want to stay with them, get to know their life, interests, duties and work. If they are willing and are able to, they can participate in the development of those interests, rest and improve their physical and psychic condition. Moreover, tourists can use the amenities available on the farm, in its proximity as well as prepared attractions and offers. Doing that, they can live in accommodation facilities maintaining good standard, in which they can prepare organic meals, enjoy living in the clean environment and be provided with health protection and legal security. Agritourism in Moldova is limited to agricultural areas and is strongly connected with plant cultivation, animal breeding, fishery or horticulture farms. 
Photograph 1 presents examples of agritourism farms in the Republic of Moldova.
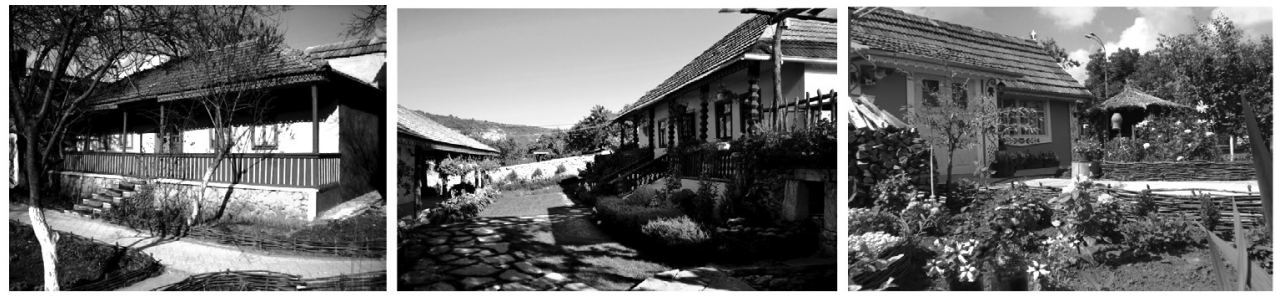

Photographs 1, 2, 3. Agritourism farms in the Republic of Moldova

Source: [Photographs by Marina Miron from the International Scientific Conference "Clusters tourist in Poland and Moldova" organized by European Cooperation Centre, Asociatia de Dezvoltare a Turismului in Moldova, Chisinau (Moldova) 22-24.06.2016].

Agritourism is still not developing in Moldova dynamically. The country is not very well known to tourists. Some tourist services providers offer coach trips to Moldova via Ukraine or Romania. However, it is a very attractive destination, in particular for tourists who make conscious choices. [http://turism.gov.md]

\section{Directions and prospects for the development of tourism in the Republic of Moldova}

To define the directions and prospects for the development of tourism in the Republic of Moldova, a SWOT analysis is presented below (Table 4).

Table 4. SWOT analysis of the development of tourism in the Republic of Moldova

\begin{tabular}{|c|c|}
\hline Strengths (S) & Weaknesses (W) \\
\hline 1 & 2 \\
\hline $\begin{array}{l}\text { - A specialist central agency subordinate } \\
\text { directly to the government manages tourism } \\
\text { - There are laws regulating tourism } \\
\text { - There are adequate documents defining } \\
\text { policies: Strategy for Sustainable } \\
\text { Development of Tourism, domestic } \\
\text { programmes: Wine Route and Moldovan } \\
\text { Rural Areas, Rural Tourism Activation } \\
\text { Programme, etc. } \\
\text { There are two active institutions: Territorial } \\
\text { Administration Collegium and Territorial } \\
\text { Administration Tourism Advisory Council }\end{array}$ & $\begin{array}{l}\text { - Moldova remains a destination appreciated by } \\
\text { - The capability to manage the tourism sector is } \\
\text { insufficient } \\
\text { - Reforms of the tourism sector management } \\
\text { are necessary } \\
\text { - There is a low level of cooperation with } \\
\text { specialists responsible for tourism locally } \\
\text { - There is a territorial imbalance between } \\
\text { management and promotion of domestic } \\
\text { tourist offer } \\
\text { - Low level of specialisation of the domestic } \\
\text { tourist offer }\end{array}$ \\
\hline
\end{tabular}




\begin{tabular}{|c|c|}
\hline 1 & 2 \\
\hline $\begin{array}{l}\text { National Training Centre for Tourism } \\
\text { Sector works Moldovan tourists support } \\
\text { the functionality of tourism industry in the } \\
\text { country Enough attractions to create a varied } \\
\text { offer for tourists Big potential of folk and } \\
\text { traditional culture (folklore, traditions, craft) } \\
\text { There are quality norms of Moldovan } \\
\text { hospitality in the destination }\end{array}$ & $\begin{array}{l}\text { - Moldova remains unknown to the European } \\
\text { citizens Personnel is not prepared to } \\
\text { Moldovan quality hospitality } \\
\text { - Activities aimed at presenting tourism at } \\
\text { - } \text { Inome and abroad are insufficient } \\
\text { - Low share in non-governmental financing of } \\
\text { projects } \\
\text { - Insufficient development of tourist services } \\
\text { infrastructure } \\
\text { - High rate of qualified staff turnover } \\
\text { Low level of cooperation with strategic } \\
\text { partners, including territorial ones }\end{array}$ \\
\hline Opportunities $(\mathrm{O})$ & Threats $(\mathrm{T})$ \\
\hline $\begin{array}{l}\text { Moldova is a member of international } \\
\text { organisations' organs (World Tourism } \\
\text { Organisation, Danube Commission for } \\
\text { Tourism, GUAM etc.) } \\
\text { - Geographical closeness to the EU and big } \\
\text { consumer markets } \\
\text { - Increase in tourist services purchase as } \\
\text { a result of improvement in services quality } \\
\text { and competitiveness } \\
\text { - There are strategies and programmes of } \\
\text { tourism development in different regions } \\
\text { - Tourism is of great interest to civil society } \\
\text { - External programmes of support for tourist } \\
\text { activities } \\
\text { - Strengthening cooperation by using national } \\
\text { heritage sites } \\
\text { - Programmes of attracting investment and } \\
\text { financial aid for tourism } \\
\text { Providing tourism personnel with increased } \\
\text { financial incentives }\end{array}$ & $\begin{array}{l}\text { - Risk connected with insufficient } \\
\text { administrative potential } \\
\text { - Lack of well-trained personnel } \\
\text { - } \text { Risk connected with the political situation } \\
\text { tourist services } \\
\text { - Limited increase or a lack of considerable } \\
\text { progress in the tourism sector } \\
\text { - Small influence of tourism on the social and } \\
\text { economic development of the society } \\
\text { - Territorial administration is seen as a sponsor } \\
\text { and tourism manager whose share on } \\
\text { a national scale is not big } \\
\text { - Large and continuous migration of people and } \\
\text { high demographic risk } \\
\text { - Low efficiency of the use of state budget } \\
\text { resources for tourism }\end{array}$ \\
\hline
\end{tabular}

Source: author's own development based on [Miron et al. 2016, pp. 213-214].

The project called "Development of agritourism clusters in Moldova, strengthening non-agricultural entrepreneurship in rural areas" (MSZ 160/2016PPR2016) financed by the Ministry of Foreign Affair of the Republic of Poland from April to November 2016 was one of opportunities to develop tourism, including agritourism in Moldova. Also the author of the article participated in the project. The Association of Tourism Development in Moldova (ADTM) and the European Cooperation Centre (Polish partner) were co-organisers of the project. Four agritourism clusters were founded in Moldova within the project: 
- Agritourism cluster "Lunca Prutului de Jos" ("Riparian forest on the Lower Prut").

- Agritourism cluster "Drumul recifilor" ("Coral reef route").

- Agritourism cluster "VILADOR".

- Agritourism cluster "Armonia Nordului" ("Northern Harmony").

\section{Conclusions}

Based on the information presented and the author's own observation, a few generalisations and conclusions can be formulated:

- The tourism sector in Moldova is inter-branch and complex one, provides visitors to the country with service hospitality, uses attractive heritage and provides recreational services for residents and tourists.

- Moldova is a small country with a variety of tourist attractions. There are over 15,000 anthropogenic tourist attractions and over 300 nature areas. 96 thousand tourists visited Moldova in 2014 ( $7.5 \%$ more than in the preceding year) generating 226 million dollars in revenues.

- Agritourism in Moldova requires that its organisers and business owners have new ideas, think in a creative way and are entrepreneurial. Entrepreneurs in rural areas must be active, ready to work and cooperate in the country and abroad and be open to the world. Such an attitude may result in the gradual improvement of services provided.

- Agritourism still is not developing in Moldova really dynamically. There were seven agritourism businesses in 2005 and 26 service providers (including 20 registered ones) in 2015.

- Cluster links may have considerable influence on the development of rural tourism, including agritourism in Moldova. The four clusters founded in rural areas may play an important role in activating local community, the region and the state. They may also have impact on actuating international areas. Agritourism clusters may transform areas into tourist ones and raise their competitiveness on the tourism market. [Roman 2013, p. 310] Specificity of clusters in tourism results from their complex tourist offer, taking into account customers' needs. [Roman 2009, pp. 188-189]

- Moldova is a country seldom visited by tourists. Similarly, there are not many scientific publications discussing issues concerning tourism, including agritourism in this country. Thus, the article may be considered innovative in character. 


\section{References}

Data of the National Bureau of Statistics of the Republic of Moldova, http://www.tourism.gov.md.

Data of the Association of Tourism Development in Moldova, http://www.agroturclas.md.

Data of the World Tourism Organisation for 2013 year.

Information from the International Scientific Conference Clusters tourist in Poland and Moldova organized by European Cooperation Centre, Asociatia de Dezvoltare a Turismului in Moldova, Chisinau (Moldova) 22-24.06.2016.

Miron V., Miron M., Krysztoforski M., Węsierski J., 2015, Agroturismul in Moldova, Pubblished Asociația de Dezvoltare a Turismului în Moldova Association of Tourism Development in Moldova, Chișinău, pp. 28, 45.

Miron V., Miron M., Roman M., Molski C., Duca A., Ciobanu S., Tomescu V., Caminschi V., Boian A., Caraman A., 2016, Clustere agroturistice in Moldova, Pubblished Asociația de Dezvoltare a Turismului în Moldova Association of Tourism Development in Moldova, Chişinău, pp. 213-214.

Raport pt. UNWTO Tourism Highlights.

Roman M., 2009, Inicjatywy klastrowe w agroturystyce na przykladzie Okopskiej Organizacji Turystycznej. Infrastruktura i Ekologia Terenów Wiejskich, no. 6, p. 188-189.

Roman M., 2013, Klastry jako forma współdziałania w działalności turystycznej, Zarządzanie i Finanse, no. 1, part 3, vol. 11, p. 310 .

Śmieja W., 2007, Mołdawia. Przewodnik turystyczny, Wydawnictwo „Piątek Trzynastego”, Łódź, p. 17. http://mkt.unwto.org/en/publication/unwto-tourism-highlights-2014-edition.

http://turism.gov.md/index.php?pag=hotel\&l.

http://www.kiszyniow.msz.gov.pl/pl/wspolpraca_dwustronna/informacje_o_moldowie/turystyka.

http://zalajkowane.pl/10-panstw-ktore-odwiedza-najmniejsza-liczba-turystow.

https://www.fly4free.pl/w-ktorych-krajach-jest-najmniej-turystow-najrzadziej-odwiedzane-panstwa/ nggallery/image/moldova-orthodox-church-shutterstock/\#galeria989. 